\title{
Hypertrophic Lichen Planus - a Case Report
}

\author{
Mirjana PARAVINA ${ }^{1 *}$ \\ ${ }^{1}$ Medical Faculty, University of Niš, Clinic of Skin and Venereal Diseases, Clinical Center of Niš, Serbia \\ *Correspondence: Mirjana Paravina, E-mail: mirjanaparavina@gmail.com \\ UDC 616.516-07/-08 \\ DE GRUYTER \\ OPEN
}

\begin{abstract}
Lichen planus is an immune, inflammatory reaction with characteristic clinical and histological lesions. It is a benign disorder, often chronic or recurrent, characterized by flat-topped, pink to purple, shiny pruritic polygonal papules on the skin, or milky white reticular papules on the visible mucous membranes.

Hypertrophic lichen planus is a chronic form of lichen planus with marked epidermal hyperplasia and intense pruritus. It is characterized by symmetrical hypertrophic plaques, usually located on the pretibial or perimalleolar regions. Lesions are often resistant to treatment.

This paper presents a patient with a giant form of verrucous lichen planus on the lower extremities, with a chronic course and resistance to various forms of therapy (keratolytics, local and intralesional corticosteroids, radiotherapy, systemic antibiotics, cryotherapy). Significant improvement was seen after 8-month treatment with etretinate (initial dose of 75 $\mathrm{mg}$ per day, with progressive reduction to $10 \mathrm{mg}$ per day). Etretinate therapy resulted in a significant regression of the disease.
\end{abstract}

\section{Key words}

Lichen Planus + physiopathology + therapy; Etretinate; Treatment Outcome

L ichen planus is a rare, immune, inflammatory tissue reaction with characteristic clinical and histological lesions (1). Several other diseases, including graft-versus-host disease, may induce lichenoid tissue reactions. Lichen planus is the prototype of all lichenoid eruptions. Its prevalence in the general population ranges from $0.5 \%$ (6) to $1 \%(7)$, even to $4 \%(8)$. The disease is benign, often chronic or recurrent, and it is characterized by flat-topped, pink to purple, shiny, pruritic, polygonal papules on the skin or milky white reticular papules on the visible mucous membranes $(2,3)$. Some describe lichen planus with the six "Ps": planar, purple, polygonal, pruritic, papules and plaques (9).

Hypertrophic lichen planus is a less common form of lichen planus. It accounts for $4.7 \%$ of lichen planus cases, and $2.2 \%$ of all lichenoid tissue reactions (10). It is a chronic, hypertrophic form of the disease with severe epidermal hyperplasia and itching (7). It is characterized by symmetrical hypertrophic plaques, usually located on the pretibial or perimalleolar regions $(4,5)$. The disease has a chronic course, and it is often resistant to treatment. Upon remission, scarring, hypo-or hyperpigmentation may follow (7, 11).

This paper presents a patient with a giant form of verrucous lichen planus on the lower extremities, with favorable results after treatment with systemic etretinate.

\section{Case report}

We present a 47-year-old housewife in good general health, except for surgical treatment of uterine myomatosis and hypertension. At the beginning, the patient presented with itchy warty growths on the sides of the heels, rapidly growing and spreading to 
other parts of the foot. They appeared on the front of the right lower leg 2-3 years later, at the site of a previous skin injury. There were no relatives with a similar disorder.

The patient was repeatedly treated at the Clinic for Skin and Venereal Diseases in Niš and once at the Military Medical Academy in Belgrade. She was treated with keratolytics, corticosteroids under occlusion and intralesional, cryotherapy with liquid nitrogen, radiotherapy (a total dose of 20 Gy, 10 sessions, two opposing fields), systemic antibiotics due to a secondary infection, sedatives, etc.), but without satisfactory long-term results. Therefore, systemic etretinate therapy was initiated.

\section{Dermatological status before etretinate therapy}

Tumor-like infiltrations, individual or confluent, were found on the sides and back of the heel, forming spurlike growths around the heels (Figure 1). Their surface was keratotic, verrucous, dark gray, and they were interspersed with rhagades producing hemorrhagicpurulent discharge under pressure. On the front right leg there was a tumor, $5 \mathrm{~cm}$ in diameter, with similar characteristics (Figure 2). The lesions were extremely pruritic, often painful, making everyday activities such as wearing shoes and walking difficult. There were no other changes on the skin and visible mucous membranes.

\section{Laboratory tests}

All required laboratory test results were within reference limits: erythrocyte sedimentation rate, complete blood count, hemoglobin, leukocyte count, urea, creatinine, liver scan, transaminases, protein electrophoresis, acid and alkaline phosphatase, lactate dehydrogenase, cholesterol, triglycerides, blood glucose, serum electrolytes; serological tests for adenoviruses, cytomegalovirus, herpes simplex virus, and Treponema pallidum. Staphylococcus aureus was isolated from the lesions, pointing to a secondary infection.

\section{Histopathological analysis}

Light microscopy of the affected skin biopsy samples showed: marked hyperkeratosis; sporadic involvement in the granular layer; uneven acanthosis, partly in the form of elongated epidermal ridges; moderate dermal infiltrations consisting mainly of lymphocytes and some histiocytes which mostly penetrated into the lower layers of epidermis, making the dermal-

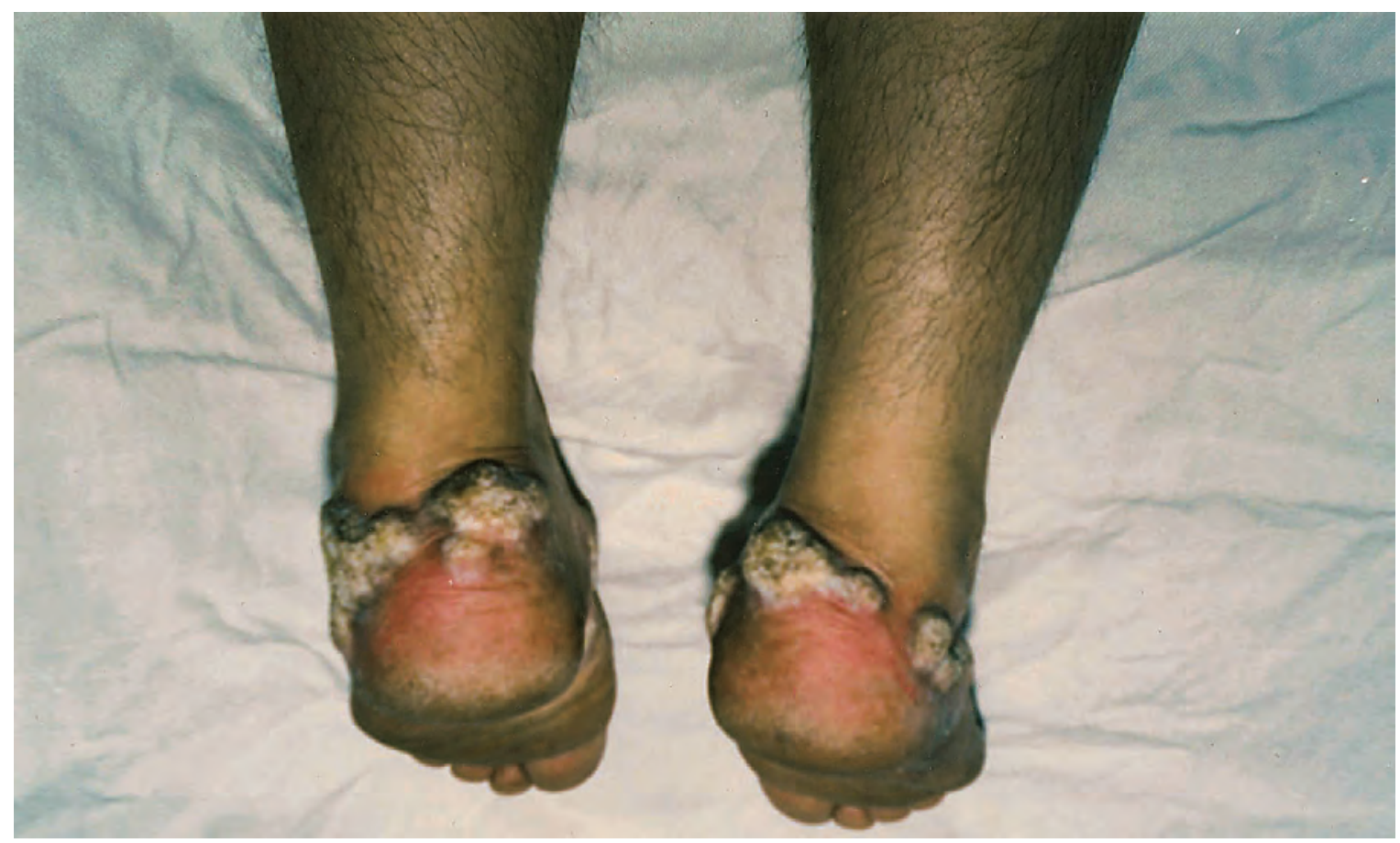

Figure 1. Spur-like lesions around the heels before etretinate therapy 


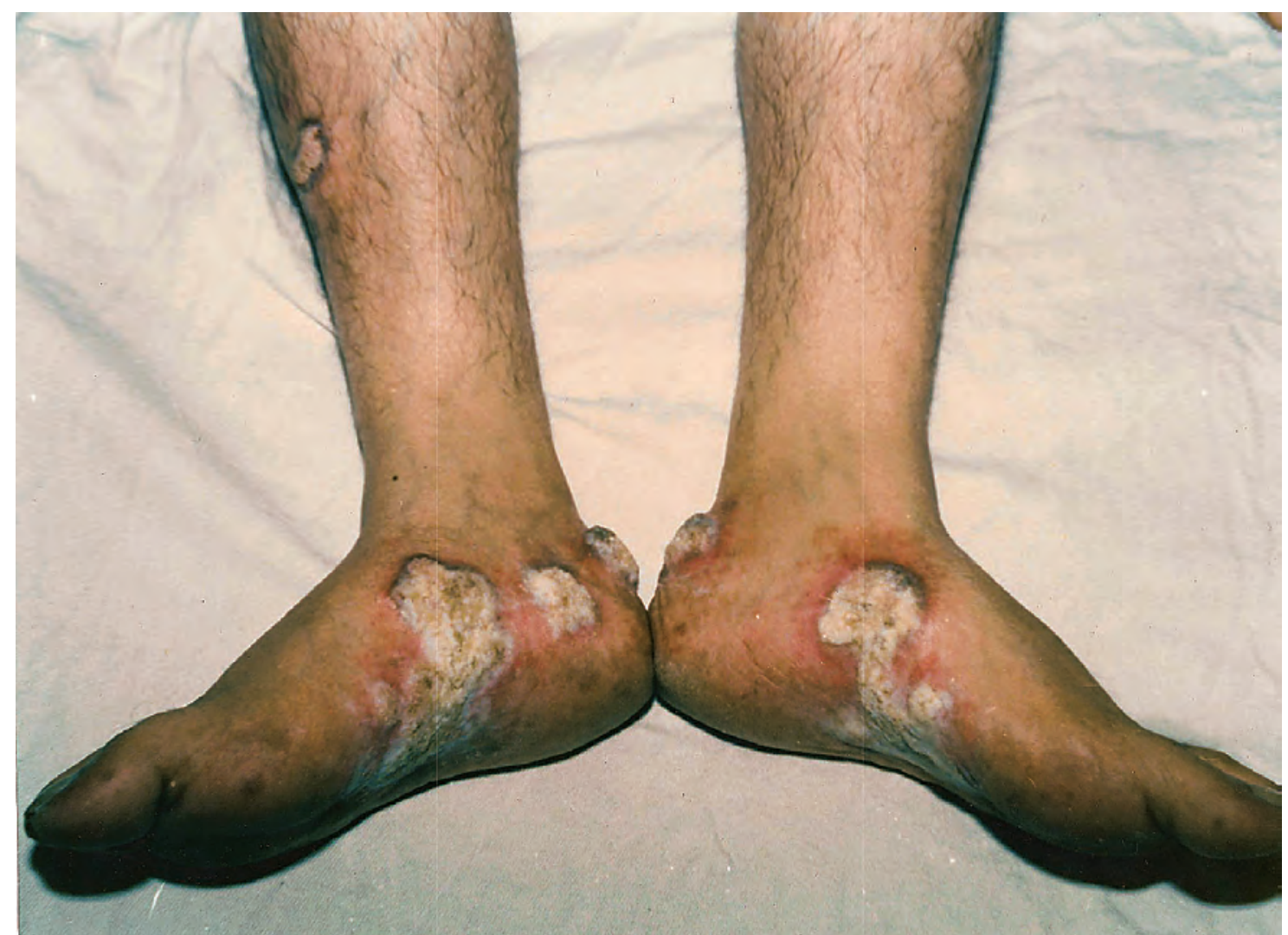

Figure 2. Skin lesions on the internal parts of the feet and on the right lower leg before etretinate therapy

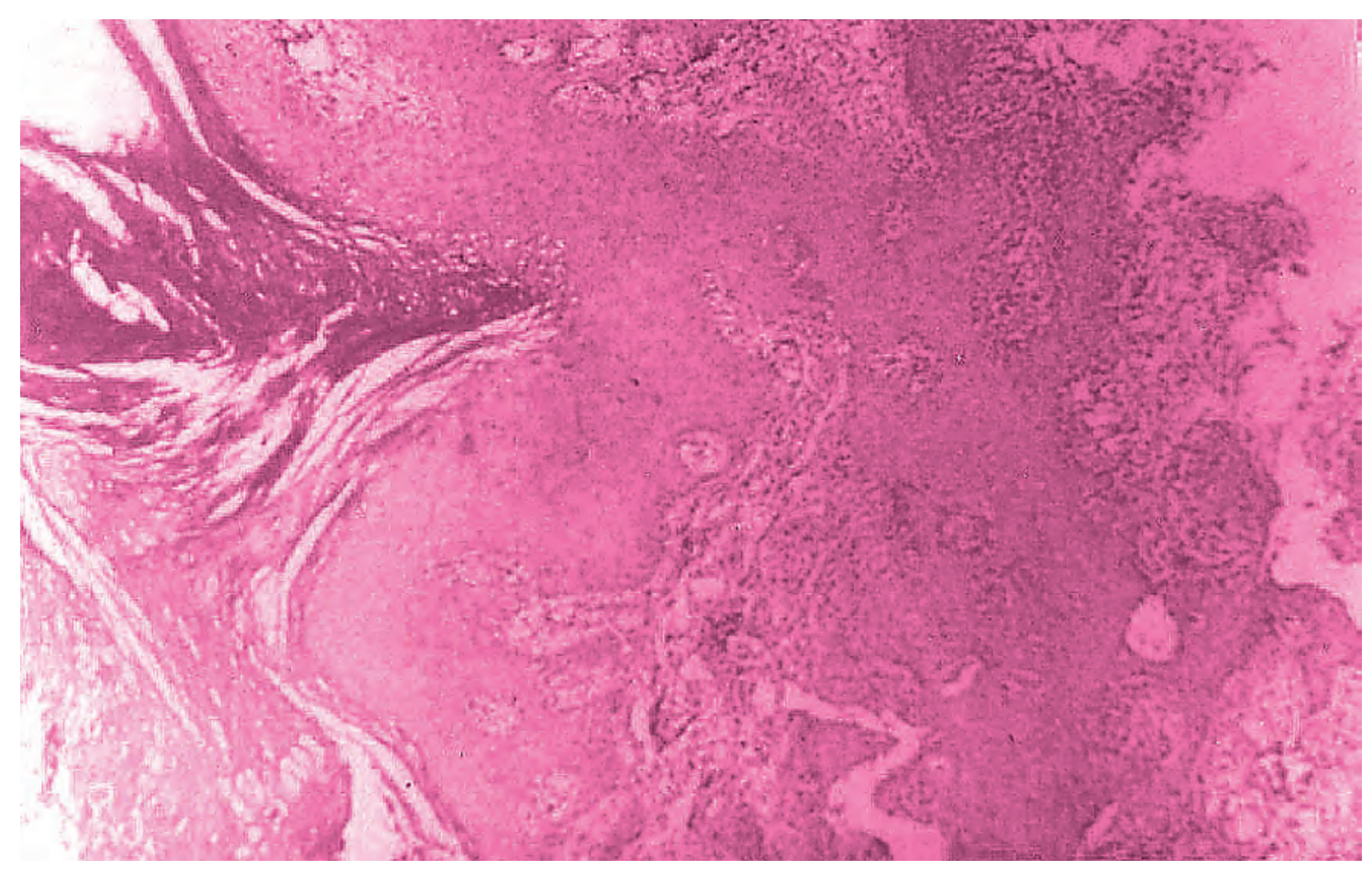

Figure 3. Histopathological finding (moth-eaten appearance) 
epidermal border unclear (moth-eaten appearance) (Figure 3).

\section{Direct immunofluorescence analysis}

Direct immunofluorescence showed findings typical for lichen palnus: fibrinogen deposits with rough jagged edges along the epidermal-dermal junction and in the blood vessel walls in the papillary dermis; multiple clustered colloid bodies (IgM) beneath the dermal-epidermal border; lines of fibrinogen deposits in the border area between the dermis and epidermis.

\section{Treatment}

Etretinate was initiated at a dose of $75 \mathrm{mg}$ per day $(3 \mathrm{x}$ $25 \mathrm{mg}$, ie. $1 \mathrm{mg} / \mathrm{kg} /$ day, with a gradual decrease to 10 $\mathrm{mg}$ per day). Topical keratolytics were used with boric lotion. The treatment lasted for 8 months. The patient reported the following side effects at the beginning of treatment: dry mouth, increased desquamation of the palms and soles, transient elevation of serum triglycerides, which was normalized after dose reduction. The therapeutic effects on skin lesions were remarkable (Figures 4 and 5). The tumefaction decreased, the heels regained nearly normal size, the patient could wear shoes, there were no secondary infections and relief of itching was significant.

During the further course of the disease, the patient suffered from a mild recurrence in the following year, so etretinate was initiated again at a dose of $0.5 \mathrm{mg} / \mathrm{kg}$ bw/day with a gradual reduction to a maintenance dose of $10 \mathrm{mg}$ every other day. In the last two years, the patient's condition remained unchanged, and her quality of life has improved. Currently, the skin lesions are located at the same sites as during the worst stage of the disease, but the infiltrates are less prominent, clearly demarcated, uneven keratotic lesions, with scattered atrophic areas circumscribed by hyperpigmentation.

\section{Discussion}

Lichen planus usually occurs between 30 and 60 years of age (1), more frequently in women. It is a chronic mucocutaneous T-cell-mediated disease, the cause of which remains unknown (12). According to Boyd and Neldner (13), there are two main types of lichen planus: "classical" idiopathic type, and lichenoid reaction

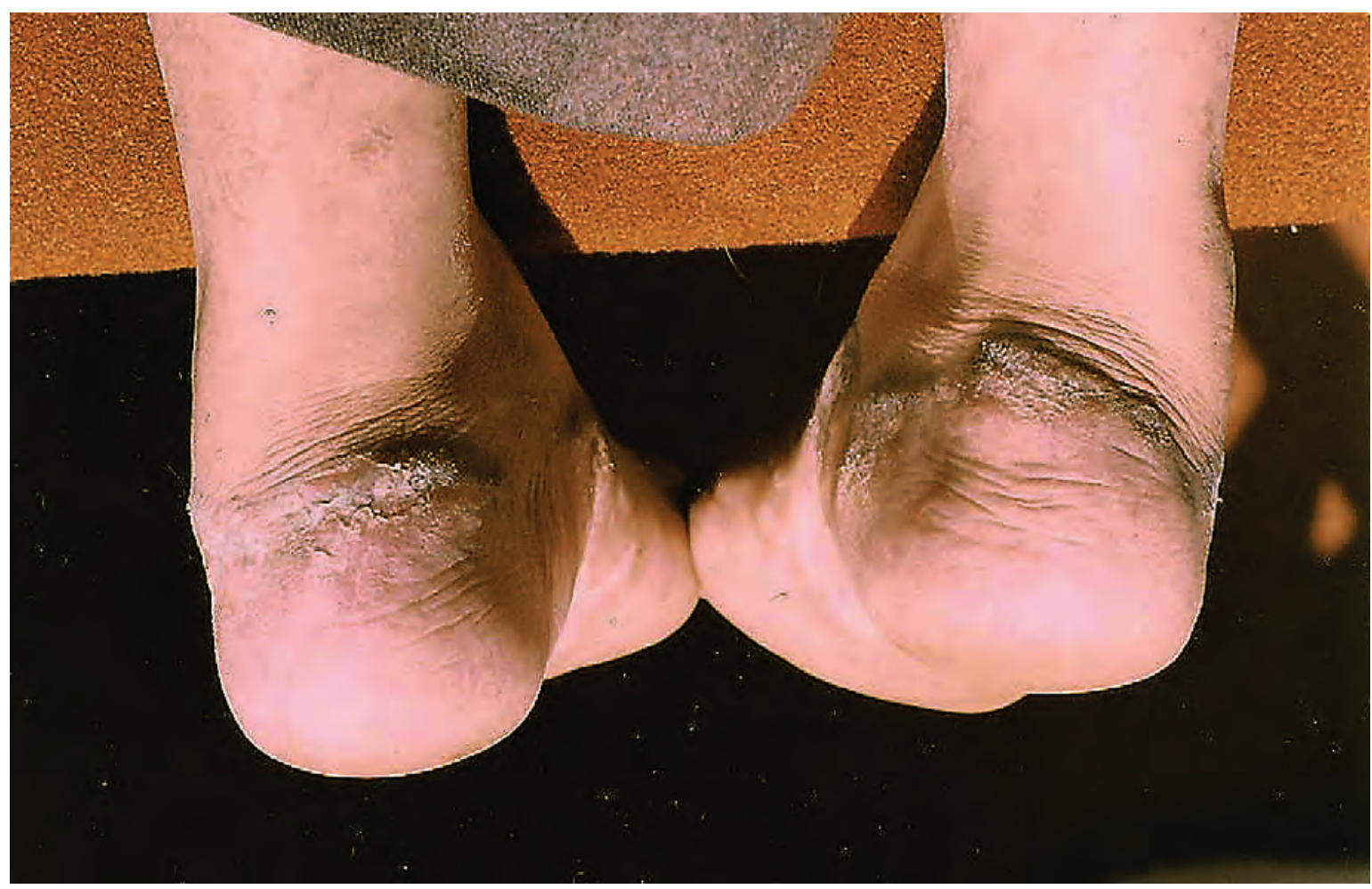

Figure 4. Regression of lesions on the heels after etretinate therapy 


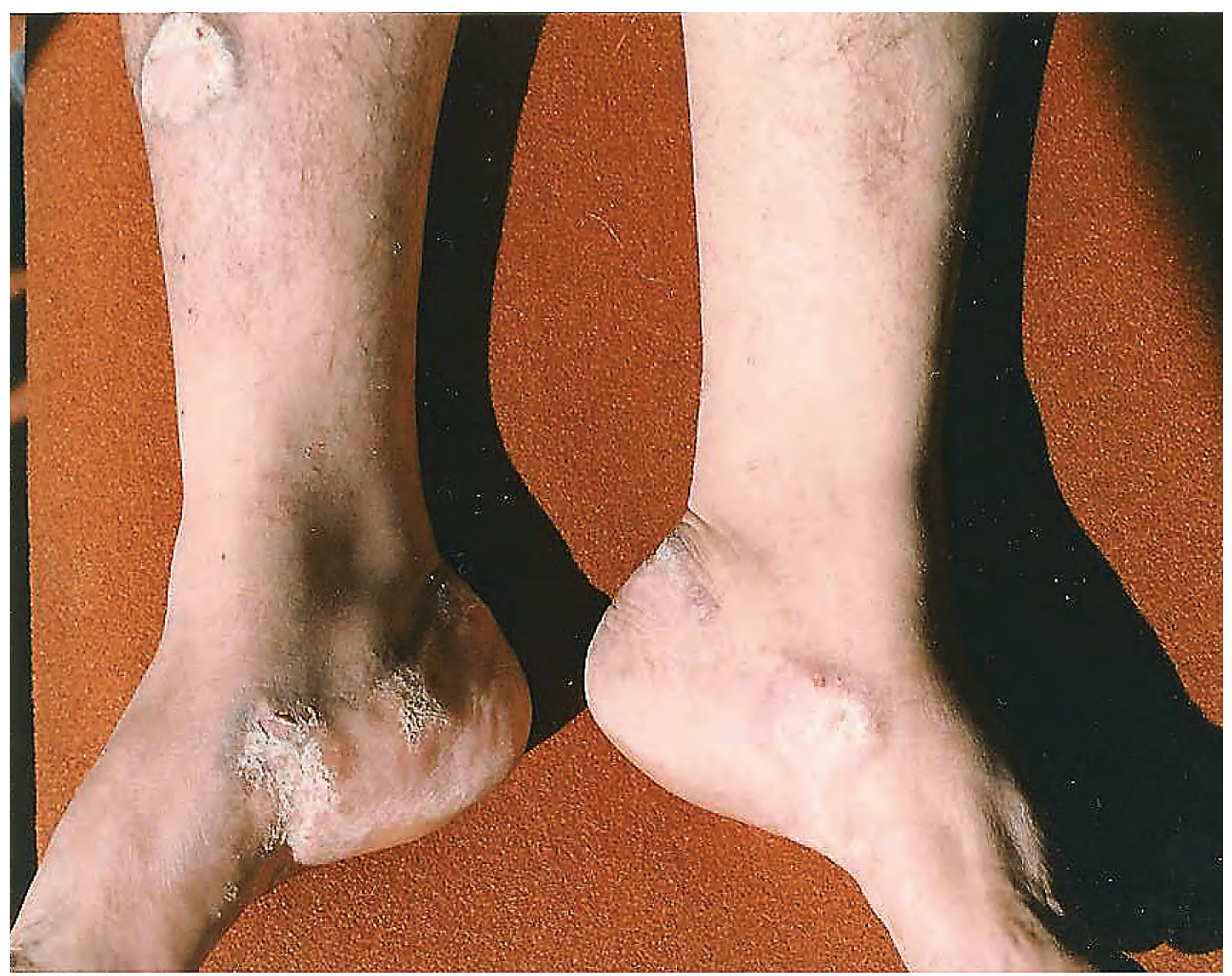

Figure 5. Regression of lesions after etretinate therapy

induced by various stimuli. The classical, idiopathic form is clinically identical to the familial form: it tends to be a severe, long-term condition, with erosive, linear or ulcerative lesions, dissemination and generalization. Genetic predisposition to the disease is associated with HLA antigens: HLA-B7,-AW19 - B18,-CW8 were found in cases of familial lichen planus, while HLAA3,-A5,-B8,-BW35 were found in non-familial cases. Oral lichen planus is associated with HLA-B8, whereas HLA-BW35 is prevalent in cutaneous forms.

There are several hypotheses on the etiopathogenesis of lichen planus (3): metabolic (decreased enzyme activities in the epidermis) (14), neurogenic and psychogenic (zosteriform pattern, association with paravertebral tumors, emotional stress, especially in emotionally labile persons) (15), and autoimmune (lichenoid eruptions with graft rejection, concomitant systemic lupus erythematosus, bullous pemphigoid eruption in generalized lichen) $(16,17)$.
Viruses, bacteria, hormones, metal ions, drugs and physical factors are considered to be potential triggers $(18,19)$. The most accepted theory is that it is a cellular autoimmune response to a viral infection $(20,21)$. Cellular components of the immune system induce epidermal reactions, injury to basal keratinocytes, and secondary inflammatory reactions $(22,23,24)$. In lichen planus lesions, CD8 $+\mathrm{T}$ cells infiltrate the epidermis while $\mathrm{T}$ cells, both CD4 + and CD8 +, accumulate in the dermis. It has been suggested that CD8+ cytotoxic T cells recognize an antigen (currently unknown) associated with the major histocompatibility complex (MHC) class I on lesional keratinocytes and lyse them (24).

Malignancy developing in lesions of lichen planus is a rare phenomenon, except in oral lichen planus (chronic inflammation and accelerated cellular turnover in erosive lesions) (25), where the risk is estimated to range from 1.1 to $3.5 \%(26,27,28)$, which is the reason 
why the WHO defines it as a pre-cancerous conditions (29). Among other localizations and clinical forms being complications of hypertrophic lichen planus of the lower extremities, the most common are neoplastic transformations and squamous cell carcinoma with a risk of metastasis $(30),(25,31,32,33,34)$.

The diagnosis is made through clinical and histopathological findings. Differential diagnosis of various forms of lichen includes several conditions (lichenoid eruptions induced by drugs or color developer, eczematous eruptions with lichenification from scratching, lichen amyloidosis), whereas in hypertrophic lichen planus, chronic lichen simplex must be excluded (19).

The choice of treatment mainly depends on the clinical type of lichen planus and its localization. According to Oliver et al (1), general principles of treatment include rest, dressings, topical steroids (mild or potent), retinoids, treatment of oral lesions and treatment of secondary or primary infections. Topical calcineurin inhibitors, such as tacrolimus $(35,36)$, pimecrolimus (37) and cyclosporine (38) are secondline therapies. Hypertrophic lesions are treated with intralesional corticosteroids. Systemic therapy includes corticosteroids, cyclosporine, dapsone, retinoids (etretinate, acitretin, isotretinoin), and PUVA therapy. If necessary, surgical treatment is performed.

Due to various mechanisms of action (39), retinoids may exhibit beneficial effects on the pathogenesis of lichen planus. Theimmunomodulatory effect is probablyachieved by restoring balance between $\mathrm{T}$ helper and $\mathrm{T}$ suppressor cells. The anti-inflammatory effect is mainly due to the inhibition of inflammatory mediators. It is believed that their specific effect is to stimulate proliferation of normal epithelial cells. On the other hand, their antiproliferative activity is based on the reduction of DNA synthesis. It is known that in healthy skin, retinoids increase the activity of glucose-6-phosphate dehydrogenase, so this mechanism of action may be involved in the pathogenesis of cutaneous lichen planus.

Our patient showed a significant improvement after etretinate therapy. Jerne et al, reported about excellent therapeutic response to acitretin in disseminated hypertrophic lichen planus (5). Recent literature has reported on the application of alitretinoin (9-cis retinoic acid) in the treatment of several cutaneous forms of lichen planus $(6,40,41)$.

\section{Conclusion}

This case report describes a patient with a rare form of verrucous lichen planus on the lower extremities. Although lesions were resistant to treatment, systemic etretinate therapy resulted in a significant regression of the disease, leading to better quality of life.

\section{References}

1. Oliver GF, Winkelmann RK.Treatment of lichen planus. Drug 1993;45(1):56-65.

2. Wolff K, Johnson RA, Suurmond D. Fitzpatrick`s Color Atlas and Synopsis of Clinical Dermatology. $5^{\text {th }}$ ed. New York: Mc Graw-Hill Medical Pubishing Division; 2005. p. 123-7.

3. Stanojević M, Paravina M. Eritemoskvamozne dermatoze. U: ParavinaM, Spalević Lj, Stanojević M, Tiodorović J, Binić I, Jovanović D. Dermatovenerologija. $2^{\text {nd }}$ ed. Niš: Medicinsi fakultet; 2006. p. 185-98.

4. Karadaglić Đ, Pavlović M. Lichen planus i lihenoidne reakcije. U: Karadaglić Đ, editor. Dermatologija. Beograd: Vojnoizdavački zavod; 2000. p. 973-84.

5. Jaime TJ, Guaraldi Bde M, Melo DF, Jeunon T, Lerer C. Disseminated hypertrophic lichen planus: relevant response to acitretin. An Bras Dematol 2011;86(Suppl 4):S96-9.

6. Pinter A, Patzold S, Kaufmann R. Lichen planus of nails successful treatment with Alitretinoin. J Dtsch Dermatol Ges 2011;9(12):1033-4.

7. Staubach P. Lichen planus. CME Dermatol 2009;4(2):68-79.

8. Zakrzewska JM, Chan ES, Thornhill MH. A systematic review of placebo - controlled randomized clinical trials of treatments used in oral lichen planus. Br J Dermatol 2005;153(2):336-41.

9. Usatine RP, Tinitigan M. Diagnosis and treatment of lichen planus. Am Fam Physician 2011;84(1):53-60.

10. Kumar UM, Yelikar BR, Inamadar AG, Umesh S, Singhal A, Kushtagi AV. A clinico-pathological study of lichenoid tissue reactions - a tertiary care experience. J Clin Diagn Res 2013;7(2):312-6.

11. Wolf R, Ruzicka T, Rupec RA. Pleomorphismus des Lichen ruber - klinische Variationsbreite, Pathogenese und Therapie. Akt Dermatol 2010;36:180-5.

12. Friedl TK, Flaig MJ, Rupec RA. Verrucous squanous cell carcinoma complicating hypetrophic lichen planus. Three case reports and review of the literature. Hautarzt 2011;62(1):40-5.

13. Boyd AS, Neldner KH. Lichen planus. J Am Acad Dermatol 1991;25(4):593-619.

14. Saurat JH, Laugier P. Lichen plan et dermatoses lichenoides. In: Saurat JH, Groshans E, Laugier P, Lachapelle JM. Dermatologie et venereologie. $2^{\text {nd }}$ ed. Paris: Masson; 1990. p. 338-43.

15. Braun Falco O, Plewig G, Wolff HH, Winkelmann RK, editors. Dermatology. Berlin: Springer Verlag; 1991.

16. De Yong EM, Van De Kerkhof PC. Coexistence of palmoplantar lichen planus and lupus erythematosus with response to treatment using acitretin. Br J Dermatol 1996;134(3):538-41.

17. Tank B, Van Joost T. Lichen planus and graft vs host disease. In: Bos JD, editor. Skin immune system (SIS). Boca Raton: CRC Press; 1997. p. 531-41. 
18. Wenzel J, Scheler M, Proelss J, Bieber T, Tuting T. Type I interferon-associated cytotoxic inflammation in lichen planus. J Cutan Pathol 2006;33(10):672-8.

19. Wagner G, Rose C, Sachse M. Clinical variants of lichen planus. J Dtsch Dermatol Ges 2013;11(4):309-19.

20. Cocchi R, Giomi A, Tuci F, Bartoli L, Sedhieri G. Pityriasis rubra pilaris, lichen planus, alopecia universalis and vitiligo in patient with chronic viral hepatitis C. Dermatology 1994;188(3):239-40.

21. Benchikhni H, Nejjam F, Habibeddine S, Jarmouni R, Lakhdar H. Lichen planus and hepatitis C. Ann Dermatol Venereol 1994;121(8):547-9.

22. Arndt KA. Lichen planus. In: Fitzpatrick TB, editor. Dermatology in generale medicine. New York Mc Graw- Hill Book Comp; 1987. p. 967-73.

23. Marks R. Retinoids in the treatment of lichen planus and lupus erythematodes. Retinoids Today and Tomorrow 1989;16:4-5.

24. Black MM. Lichen planus and lichenoid disorders. In: Rook`s Textbook of Dermatology. $5^{\text {th }}$ d. Oxford: Blackwel Scientific Publ; 1992. p. 1675-98.

25. Singh SK, Saikia UN, Ajith C, Kumar B. Squamous cell carcinoma arising from hypertrophic lichen planus. J Eur Acad Dermatol Venereol 2006;20(6):745-6.

26. Bromwich M. Retrospective study of the progression of oral premalignant lesions to squamous cell carcinoma: South Wales experiance. J Otolaryngol 2002;31(3):150-6.

27. Gandolfo S, Richiardi I, Carrozzo M, Broccoletti R, Carbone M, Pagano M, et al. Risk of oral squamous cell carcinoma in 402 patients with oral lichen planus: a follow-up study in an Italian population. Oral Oncol 2004;40(1):77-83.

28. Van der Meij EH, Mast H, van der Waal I. The possible premalignant character of oral lichen planus and oral lichenoid lesions: a prospective five-year follow-up study of 192 patients. Oral Oncol 2007;43(8):742-8.

29. Pindborg JJ, Reichart PA, Smith CJ, van der Waal I. Histo-logical typing of cancer and precancer of theoral mucosa. In: WHO international classification of skin tumors. Berlin: Springer; 1997.
30. Ardabili M, Gambichler T, Rotterdam S, Altmeyer P, Hoffmann K, Stucker M. Metastatic cutaneous squamous cell carcinoma arising from a previous area of chronic hypertrophic lichen planus. Dermatol Online J 2003;9(1):10.

31. Sigurgeirsson B, Lindelof B. Lichen planus and malignancy. An epidemiologic study of 2071 patients and review of the literature. Arch Dermatol 1991;127(11):1684-8.

32. Manz B, Paasch U, Sticherling M. Squamous cell carcinoma as a complication of long-standing hypertrophic lichen planus. Int J Dematol 2005;44(9):773-4.

33. Campanati A, Marconi B, Penna L, Giangiacomi M, Offidani A. A case of hypertrophic lichen ruber planus of the leg complicated by a squamous cell carcinoma. Int J Dermatol 2003;42(5):415-6.

34. Kolios AG, Marques Maggio E, Gubler C, Cozzio A, Dummer $\mathrm{R}$, French LE, et al. Oral, esophageal and cutaneous lichen ruber planus controlled with alitretinoin: case report and review of the literature. Dermatology 2013;226(4):302-10.

35. Thomson MA, Hamburger J, Stewart DG, Lewis HM. Treatment of erosive oral lichen planus with topical tacrolimus. J Dermatolog Treat 2004;15(5):308-14.

36. Sonthalia S, Singal A. Comparative efficacy of tacrolimus $0.1 \%$ ointment and clobetasol propionate $0,05 \%$ ointment in oral lichen planus: a randomized double- blind trial. Int J Dermatol 2012;51(11):1371-8.

37. Swift JC, Rees TD, Plemons JM, Hallmon WW, Wright JC. The effectiveness of $1 \%$ pimecrolimus cream in the treatment of oral erosive lichen planus. J Periodontol 2005;76(4):627-35.

38. Eisen D, Carrozzo M, Bagan Sebastian JV, Thongprasom $\mathrm{K}$, Number V. Oral lichen planus: clinical features and management. Oral Dis 2005;11(6):338-49.

39. Dostanić I. Retinoidi u dermatološkoj praksi. Beograd: Dostanić N; 1995. p. 10-4

40. Brehmer F, Haenssle HA, Schon MP, Emmert S. Response of recalcitrant lichen planus to alitretinoin i 3 patients. J Am Acad Dermatol 2011;65(2):e58-60.

41. Molin S, Ruzicka T. Oral alitretinon in lichen planus: two case reports. Acta Derm Venereol 2010;90(5):523-4.

\section{Hipertrofični lihen planus - prikaz slučaja}

\section{Sažetak}

Uvod. Lichen planus je inflamatorna imunska reakcija sa karakterističnim kliničkim i histološkim lezijama. Bolest je benignog, često hroničnog ili recidivantnog toka, a karakterišu je zaravnjene ružičaste do ljubičaste sjajne pruritične poligonalne papule na koži ili mlečnobele retikularne papule na vidljivoj sluzokoži.

Lichen planus hypertrophicus je hronična hipertrofijska forma bolesti, sa naglašenom epidermalnom hiperplazijom i jakim svrabom. Karakterišu je simetrični hipertrofični plakovi, najčešće lokalizovani pretibijalno i perimaleolarno. Lezije su često rezistentne na terapiju. Prikaz slučaja. Prikazuje se 47 godina stara domaćica, dobrog opšteg stanja: osim operativnog lečenja miomatoznog uterusa i hipertenzije u prošlosti nije bilo drugih oboljenja; bolest je počela na bočnim stranama peta u vidu bradavičastih izraslina praćenih svrabom koje su se brzo povećavale i širile na susedne delove stopala: na prednjoj strani desne potkolenice nastale su 2-3 godine kasnije i to na mestu prethodne povrede kože; u porodici nije bilo obolelih srodnika.

Bolesnica je u više navrata lečena na Klinici za kožne i polne bolesti u Nišu i jednom na Vojnomedicinskoj akademiji u Beogradu. Primenjena terapija (keratolitici, kortikosteroidi pod okluzijom i intraleziono, krioterapija 
tečnim azotom, zračna terapija X-zracima - ukupna primljena doza od 20 Gy data u 10 seansi na dva suprotna polja, sistemski antibiotici prema antibiogramu zbog sekundarne infekcije, sedativi, itd.) nije dala zadovoljavajuće i trajnije rezultate. Zbog toga je odlučeno da se primeni etretinat u obliku kapsula.

U momentu pregleda, na bočnim i zadnjim stranama peta bili su prisutni infiltrati tumoroznog izgleda, pojedinačni ili sliveni, koji su davali izgled mamuza oko peta. Površina im je bila keratotična, verukozna, sivkasto mrko prebojena, ispresecana ragadama, iz kojih se na pritisak cedio hemoragično purulentan sadržaj. $\mathrm{Na}$ prednjoj strani desne potkolenice bio je prisutan tumefakt oko $5 \mathrm{~cm}$ u prečniku, sličnih osobina. Promene su bile jako pruritične, često bolne, onemogućavale su nošenje obuće i otežavale hod. Drugih promena na koži i vidljivim sluzokožama nije bilo.

Sve tražene laboratorijse analize su bile u granicama referalnih vrednosti: sedimentacija eritrocita, kompletna krvna slika, hemoglobin, leukocitarna formula, urea, kreatinin, hepatogram, transaminaze, elektroforeza proteina, kisela i alkalna fosfataza, laktat-dehidrogenaza, holesterol, trigliceridi, glikemija, elektroliti u serumu; serološke reakcije na adenoviruse, citomegalovirus, herpes simpleks virus i Treponema pallidum. Staphylococcus aureus je bio izolovan iz lezija koje su pokazivale znake sekundarne infekcije.

Svetlosnom mikroskopskom analizom bioptiranog uzorka promenjene kože uočeno je sledeće: veoma izražena hiperkeratoza; granulozni sloj samo mestimično naznačen; nejednako izražena akantoza, delimično $\mathrm{u}$ vidu epidermalnih produžetaka; umereno gust infiltrat u dermisu, sastavljen najvećim delom od limfocita i ređih histiocita koji u većem delu preparata prodire i u donje slojeve epidermisa, te je epidermo-dermalna granica nejasna - kao izjedena moljcima).

Direktnom imunofluorescencijom je dobijen nalaz koji je ukayivao na lihen palnus: depoziti fibrinogena $\mathrm{u}$ vidu grube nazubljene trake duž epidermo-dermalne granice i u zidovima krvnih sudova papilarnog dermisa intenzivne fluorescencije; brojna koloidna tela klase IgM u većim grupama ispod epidermo-dermalne granice; trakasti depoziti fibrinogena na graničnom delu između epidermisa i dermisa.

Terapija. Lečenje etretinatom započeto je dozom od 75 $\mathrm{mg}$ na dan (3 puta $25 \mathrm{mg}$, tj. oko $1 \mathrm{mg}$ na kg na dan, sa postepenim smanjivanjem na $10 \mathrm{mg}$ na dan). Lokalno su primenjivani keratolitici u bornom kremu. Kura je trajala 8 meseci. U početku lečenja od neželjenih efekata javila se suvoća usta, pojačana deskvamacija dlanova i tabana, prolazno povišenje triglicerida u serumu koje se normalizovalo sa smanjenjem doze. Efekat terapije na promene na koži je bio izvanredan. Došlo je do izravnavanja tumefakta, pete su dobile skoro normalan obim, bolesnica je mogla da nosi cipele, nije bilo sekundarne infekcije i bitno je smanjen svrab.

Diskusija. Izbor terapije za lihen planus zavisi od kliničke forme i lokalizacije promena. Prema Oliveru i saradnicima, opšti principi lečenja lihena obuhvataju: odmor, previjanje, topikalne steroide (srednji ili potentni), retinoide, lečenje oralnih lezija i tretman sekundarne ili primarne infekcije. Lokalno se mogu primeniti i inhibitori kalcineurina, kao što je takrolimus, pimekrolimus i ciklosporin. Kod hipertrofijske forme kortikosterodi se aplikuju intraleziono. Sistemski se primenjuju kortikosteroidi, ciklosporin, dapson, retinoidi (etretinat, acitretin, isotretinoin), PUVA terapija. Po potrebi se mogu koristiti i hirurške metode. Retinoidi, zbog svojih raznovrsnih mehanizama dejstva mogu da deluju na različitim nivoima u patogenezi lihena planus. Imunomodulatorno dejstvo se najverovatnije ostvaruje uspostavljanjem ravnoteže između T-pomažućih (helper) i T-supresorskih limfocita. Antiinflamatorni efekat je uglavnom posledica inhibicije medijatora inflamacije. Smatra se da je specifično dejstvo retinoida da stimulišu proliferaciju normalnih epidermalnih ćelija. S druge strane, njihovo antiproliferativno dejstvo zasniva se na redukciji sinteze DNA. Poznato je da retinoidi u zdravoj koži povećavaju aktivnost glukoza 6 fosfat-dehidrogenaze, pa bi i ovaj mehanizam dejstva mogao biti uključen u patogenezi lihenskih promena.

Kod naše bolesnice do bitnog poboljšanja došlo je tek posle primene etretinata. Džeme (Jeme) i saradnici navode odličan terapijski odgovor na acitretin ostvaren kod diseminovanog hipertrofijskog lihena. U novijoj literaturi ima više izveštaja o primeni alitretinoina (9-cis retinoic acid) u lečenju nekoliko kutanih oblika lihena. Zaključak. Prikazana je bolesnica sa retkom formom verukoznog lihena sa lokalizacijom na donjim ekstremitetima, sa rezistencijom na bilo koju terapiju do sistemske primene retinoida, etretinata. To je znatno olakšalo stanje bolesnice i dovelo do poboljšanja kvaliteta njenog života.

\section{Ključne reči}

Lichen planus + fiziopatologija + terapija; Etretinat; Ishod lečenja 